\title{
Occurrence of Whip Spiders (Arachnida:Amblypygi) in Isolated Fragments of Atlantic Forest in a Northeastern Brazilian Metropolis: Perspective for New Studies
}

\author{
Kátia Regina Benati1 ${ }^{1}$, Marcelo Alves Dias ${ }^{1}$, Marcelo Cesar Lima Peres ${ }^{1,2}$, Alessandra \\ Rodrigues S. de Andrade ${ }^{1,3}$, Sheila Luzia de Santana Varjão ${ }^{1}$, Daniela Uzel Sena ${ }^{1,4}$, \\ Tércio da Silva Melo ${ }^{1,3}$ \\ ${ }^{1}$ Centro de Ecologia e Conservação Animal (ECOA) da Universidade Católica do Salvador (UCSal), \\ Bahia, Brasil. \\ ${ }^{2}$ Programa de Pós-Graduação em Planejamento Ambiental (PPGPA) da Universidade Católica do \\ Salvador (UCSal), Bahia, Brasil. \\ ${ }^{3}$ Programa de Pós-Graduação em Ecologia e Biomonitoramento da Universidade Federal da Bahia, \\ Salvador, Bahia, Brasil. \\ ${ }^{4}$ Faculdade Estácio de Alagoas (FAL). Alagoas, Maceió, Brasil.
}

\begin{abstract}
The objective was to register occurrence of the genus Charinus Simon, 1892, in two isolated fragments of Atlantic Rain Forest in Salvador; the Metropolitan Park of Pituaçu with 382 ha and $19^{\circ}$ "Batalhão de Caçadores" - Brazilian Army with about 166 ha. A total of 17 individuals have been collected through samples of leaflitter, all of them from genus Charinus. Although the reduced abundance, it was noted that the individuals of this sort can be found in urban fragments that show high degree of isolation and with historical of intense anthropic perturbation, however, the richness is rather low.
\end{abstract}

Keywords: amblypygids, Charinus, Urban Forest Fragment, biodiversity refuges, urban environmental degradation.

\section{INTRODUCTION}

Urban forest fragments are excellent refuges for various groups of animals and plants, which otherwise could not remain in predominantly urban areas (Brown Jr \& Freitas, 2003; Vasconcelos et al., 2009).

The order Amblypygi consists of five families, composed of 136 species (Harvey, 2002), distributed mainly in the tropics, which occur in the formations of forest and caves (Harvey, 2003). They are strictly nocturnal animal habits, and many species are troglomorphic (Weygoldt, 2000).Commonly known as whip spiders.

Amblypygids are little known animals, being included in the group of microdiverse arachnids, which have been neglected in relation to megadiverses: Araneae, Acariformes and Parasitiformes (Harvey, 2002), which justifies the need to intensify studies related to this order. 23 Neotropical species of the genus Charinus (Giupponi\&Kury, 2002) are known, seven of which occur in Brazil, being: $C$. schirchii Mello-Leitão, 1931; C. brasilianus Weygoldt, 1972; C. montanus Weygoldt, 1972; C. asturius Pinto da Rocha, Machado \&Weygoldt, 2002; C. acaraje Pinto da Rocha, Machado \& Weygoldt, 2002; C. mysticus Giupponi\& Kury, 2002; C. troglobius Baptista \&Giupponi, 2002 and C. eleonorae. The specimens collected in this study belong to a new species of the genus Charinus that is being described by Giupponi, APL (National Museum of Rio de Janeiro - UFRJ).

The objective was to record the occurrence of non-troglomorous amblypygids in fragments isolated from the Atlantic Forest of Northeast Brazil.

\section{Materials AND Methods}

Six fragments were studied in the urban area of Salvador, Bahia. The dominant vegetation is the Atlantic Rain Forest, which predominates on the Brazilian Atlantic coast, these fragments are part of priority areas for the conservation of invertebrates, which is classified in status of high biological importance (Conservation International do Brasil et al., 2000). The "Parque Metropolitanode Pituaçu - 
PMP (12 ${ }^{\circ} 56^{\prime} 33$ "S and $\left.38^{\circ} 24^{\prime} 22^{\prime \prime} \mathrm{W}\right)$ which has 382 ha; the forest fragment of the $19^{\circ}$ "Batalhãode Caçadores" -19BC (12 ${ }^{\circ} 57^{\prime} 33$ "S and $\left.38^{\circ} 27^{\prime} 34^{\prime \prime W}\right) 166$ ha; the 4th "Companhia de Guarda de Salvador" - $4^{\mathrm{a}} \mathrm{CG}\left(12^{\circ} 58^{\prime} 29.67\right.$ "S $\left.38^{\circ} 26^{\prime} 35.17^{\circ} \mathrm{W}\right)$ with $60 \mathrm{ha}$; the forest fragment of the company "Grande Moinho Aratu" -GMA (1247'32 "8S 38 28'15,3" W), 5ha; the "Jardim Botânico de Salvador - JBS, (12059'57.99 "S 38 $\left.28^{\prime} 17.12^{\prime \prime} \mathrm{W}\right)$ with 18ha and the "Parque Juventino Silva" - PJS (12 $59^{\circ} 57.99$ "S 38 28'17.12" W), with 72 hectares.

Sampling was carried out in the sporadic period from 2000 to 2008. The following collection methods were applied in their respective study areas: pitfall trap (19 BC, GMA, PJS and PMP), nocturnal manual collection (4th-GS, JBS, PJS and PMP), Berlese funnel (19 BC, GMA and PMP) and the Winkler Extractor (GMA, PJS, JBS and 4th-GS). In total, 367 samples of 50x50cm litter (totaling $92 \mathrm{~m} 2$ ) were installed, 390 pitfalls were installed, and a sampling effort of $115 \mathrm{~h}$ nocturnal.

\section{RESUlTS AND DISCUSSION}

Eighteen specimens of amblypygids were found in the "Parque Metropolitano de Pituaçu" in the leaf litter samples, using the Berlese funnel in the year 2004 and only one in the 19BC, through the pitfall trap in 2005. Amblypygids were more abundant in areas with dense canopy and with a higher frequency of fallen logs, confirming Baptista \& Giupponi (2002), who indicate that in Brazil most species of this genus live under logs and rocks in the Atlantic Forest.

Despite the occurrence of the genus Charinus in Atlantic Forest environments, it has already been reported by Baptista \& Giupponi (2002) and Pinto-da-Rocha et al. (2002), this is the first record of the genus Charinus to the city of Salvador, since in previous works (Baptista \& Giupponi, 2002, Giupponi \& Kury, 2002) report the occurrence of this genus in Bahia associated only to the caves of The Serra do Ramalho in Carinhanha, Pedra do Sino in Santa Luzia and Encantados in Gentio do Ouro.

Dias and Machado (2006) have found that amblypygids have a preference for large trees and suggest that human disturbance promoted by selective logging or forest degradation due to habitat fragmentation and edge effect may have a negative effect on the spatial distribution and therefore on the density of these animals. Therefore, considering the great effort in time and space and the variety of methods used, it is inferred that the intense human pressure on the urban systems of Atlantic Rains Forest, causes a significant reduction in abundance and richness of the order Amblypygi.

\section{ACKNOWLEDGMENTS}

The authors are grateful to the Alessandro Giupponi of the National Museum of Rio de Janeiro (UFRJ) for the identification of the specimens. We appreciate the logistical support in the exits offered by the UCs, the military and private areas, and also by the security of the police of the Company of Protection of Environmental Police. M.C.L.P. Receives support from the Regime of Continuous Time (RTC) of the Universidade Católica do Salvador.

\section{REFERENCES}

Baptista, R.L.C. \&Giupponi, A. P. L. 2002. A new troglomorphicCharinusfromBrazil (Arachnida: Amblypygi: Charinidae). Revista Ibérica de Aracnología, 6: 105-110.

Brown JR., K. S. \& Freitas, A. V. L. 2003. Butterfly communities of urban forest fragments in Campinas, São Paulo, Brazil: structure, environment correlates, and conservation. Journal of Insect Conservation, 6: 217-231p.

ConservationInternational do Brasil, Fundação SOS Mata Atlântica, Fundação Biodiversitas, Instituto de Pesquisas Ecológicas, Secretaria do Meio Ambiente do Estadode São Paulo (SEMAD) and Instituto Estadual de florestas / MG. 2000. Avaliação e Ações Prioritárias para Conservação da Biodiversidade da Mata Atlântica e Campos Sulinos. Brasilia: Secretaria de Biodiversidade e Florestas (SBF), Ministério do Meio Ambiente e dos Recursos Hídricos e da Amazônia Legal (MMA).

Dias S.C. \& Machado, G. 2006. Microhabitat use by the whip spider Heterophrynuslongicornis (Amblypygi, Phrynidae) in Central Amazon. The Journal of Arachnology, 34:540-544.

Giupponi, A.P.L. \&Kury, A.B. 2002. New species of Charinus Simon, 1892 from Northeastern Brazil (Arachnida, Amblypygi, Charinidae). Boletim do Museu Nacional, 477: 1-7. 
Occurrence of Whip Spiders (Arachnida: Amblypygi) in Isolated Fragments of Atlantic Forest in a Northeastern Brazilian Metropolis: Perspective for New Studies

Harvey, M.S. 2002. The neglected cousins: what do we know about the smaller arachnid orders? The Journal of Arachnology. 30: 357-372.

Harvey, M.S. 2003. Catalogue of the Smaller Arachnid Orders of the World: Amblypygi, Uropygi, Schizomida, Palpigradi, Ricinulei and Solifugae. CSIRO Publishing, Collingwood, Victoria, AU, 400p.

Pinto-da-Rocha, R., Machado, G., Weygoldt, P. 2002. Two new species of Charinus Simon 1892 from Brazil with biological notes (Arachnida; Amblypygi; Charinidae). Journalof Natural History. 36 (1): 107-118.

Vasconcelos, R. N.; Barbosa, E. C. C. \& Peres, M. C. L. 2009. Borboletas do parque metropolitano de Pituaçu, Salvador, Bahia, Brasil. Sitientibus Série Ciências Biológicas,9(2/3):158-164p.

Weygoldt,P.2000.Whipspiders (Chelicerata:Amblypygi). Their biology, morphology and systematics. Apollo Books, Stenstrup, Denmark, 163pp.

Citation: K. Benatil, "Occurrence of whip Spiders (Arachnida:Amblypygi) in Isolated Fragments of Atlantic Forest in a Northeastern Brazilian Metropolis: Perspective for New Studies", International Journal of Research Studies in Biosciences (IJRSB), vol. 5, no. 8, p. 3, 2017. http://dx.doi.org/10.20431/2349-0365. 0508001

Copyright: (C) 2017 Authors. This is an open-access article distributed under the terms of the Creative Commons Attribution License, which permits unrestricted use, distribution, and reproduction in any medium, provided the original author and source are credited. 